Journal of Telenursing

Volume 2, Nomor 1, Juni 2020

e-ISSN: 2684-8988

p-ISSN: 2684-8996

DOI: https://doi.org/10.31539/joting.v2i1.1096

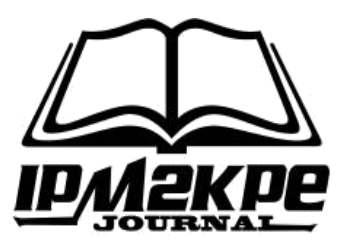

\title{
PERUBAHAN SENSITIVITAS KAKI PADA DIABETES MELITUS TIPE 2 SETELAH DILAKUKAN SENAM KAKI
}

\author{
Laras Sri Ningrum ${ }^{1}$, Tini Wartini ${ }^{2}$, Isnayati ${ }^{3}$ \\ Akademi Keperawatan Pelni Jakarta ${ }^{1,2,3}$ \\ tini.wartini99@yahoo.co.id ${ }^{2}$
}

\begin{abstract}
ABSTRAK
Tujuan penelitian untuk mengetahui efektifitas senam kaki diabetik terhadap sensitivitas kaki pasien diabetes mellitus tipe 2. Metode yang digunakan dalam penelitian ini merupakan metode penelitian deskriptif dengan pendekatan studi kasus. Hasil penelitian menunjukkan saat dilakukan pengukuran sensitivitas kaki setelah dilakukan senam kaki 2x/hari selama 3 hari terjadi perubahan. Perubahan nilai sensitivitas meningkat 1-2 point dari point maksimal 3. Simpulan, pelaksanaan senam kaki dapat meningkatkan sensitivitas kaki pada pasien diabetes melitus tipe 2 .
\end{abstract}

Kata Kunci : Diabetes Mellitus Tipe 2, Senam Kaki, Sensitivitas Kaki

\section{ABSTRACT}

This study aimed to determine the effectiveness of diabetic foot exercises on the sensitivity of the feet of Type 2 Diabetes Mellitus patients. The method used in this study was a descriptive research method with a case study approach. The results showed when measuring the feet' sensitivity after doing leg exercises $2 x /$ day for three days, and there was a change. The change in sensitivity value increases 1-2 points from the maximum point 3. Conclusions The implementation of foot exercises can increase the sensitivity of the foot in type 2 diabetes mellitus patients.

Keywords: Diabetes Mellitus Type 2, Foot Gymnastics, Foot Sensitivity

\section{PENDAHULUAN}

Menurut World Health Organization (WHO, 2015) jumlah orang dengan diabetes telah meningkat dari 108 juta pada tahun 1980 menjadi 422 juta pada tahun 2014 . Pada 2015 sekitar 1,6 juta kematian secara langsung disebabkan oleh diabetes WHO memprediksi bahwa diabetes akan menjadi penyebab kematian ketujuh di tahun 2030. Indonesia menempati peringkat ke -7di dunia sebesar 10 juta jiwa (Sulistyowat, Asnindari, 2017).

Indonesia menempati peringkat ke-7 di dunia sebesar 10,0 juta jiwa, dimana peringkat pertama diduduki oleh China dengan jumlah penderita DM 109,6 juta jiwa Menurut Laporan Riset Kesehatan Dasar (Riskesdas) prevalensi penderita DM pada tahun $2013(2,1 \%)$ mengalami peningkatan dibandingkan pada tahun $2007(1,1 \%)$. Angka kejadian DM di Jawa Tengah sebesar 1,6 \% dan menempati urutan kelima dari seluruh provinsi yang ada di Indonesia (IDF, 2015). 
Prevalensi DM meningkat diakibatkan banyaknya pasien DM yang belum mendapat pengobatan maupun yang sudah mendapat pengobatan namun kadar gula dalam darahnya belum mencapai target normal serta adanya Komplikasi yang dialami oleh pasien (Padila, 2012; Fatimah, 2015).

Diabetes Melitus (DM) merupakan penyakit kelompok gangguan metabolik yang ditandai oleh peningkatan kadar gula darah yang disebabkan oleh kurangnya insulin, tidak mampu insulin bekerja atau keduanya. Klasifikasi DM dibagi menjadi beberapa bagian yaitu DM tipe 1 (IDDM = Insulim Dependen Diabetes Melitus), DM tipe 2 (NIDDM = Non Insulin Dependen Diabetes Melitus). DM kehamilan dan DM yang berhubungan dengan kondisi lainnya.

Pengelolaan penyakit DM dikenal dengan empat pilar utama yaitu penyuluhan atau edukasi, terapi gizi medis, latihan jasmani atau aktivitas fisik dan intervensi farmakologis. Keempat pilar pengelolaan tersebut dapat diterapkan pada semua jenis tipe DM termasuk DM tipe II. Untuk mencapai fokus pengelolaan DM yang optimal maka perlu adanya keteraturan terhadap keempat pilar utama tersebut (Perkeni, 2015).

Latihan senam kaki menyebabkan terjadinya peningkatan aliran darah. Hal ini menyebabkan lebih banyak tersedia reseptor insulin dan reseptor menjadi aktif yang akan berpengaruh terhadap penurunan glukosa darah pada pasien diabetes (Sulistyowati, Asnindari, 2017).

Hasil Penelitian Khaerunnisa (2019) senam kaki merupakan salah satu tindakan keperawatan yang dapat menurunkan gluko sa darah dan sensitivitas kaki. Instrumen yang digunakan adalah pedoman wawancara, lembar ceklist dan catatan dokumentasi pasien. Data dianalisis berdasarkan hasil wawancara, pengukuran glukosa darah sewaktu dan sensitivitas kaki sebelum dan sesudah latihan senam kaki. Hasil penelitian menunjukkan penurunan gula darah sewaktu sebanyak $75 \%$ responden sesudah latihan senam kaki pada latihan ketiga dengan frekuensi latihan 3 kali seminggu. Sebanyak $25 \%$ responden tidak mengalami perbaikan akibat tidak mampu mengontrol diet. Hal ini berpengaruh pada peningkatan sensitivitas kaki pada responden.

Menurut hasil penelitian Penelitian Anggraini (2017) Untuk mengetahui adanya pengaruh senam kaki terhadap kadar gula darah sewaktu pada penderita diabetes mellitus tipe II di wilayah kerja Puskesmas Cawas 1. Metode Penelitian: Desain penelitian pretest-posttest control group design. Uji statistik menggunakan Paired t-test, Wilcoxon, Independent t-test. Teknik pengambilan sampel yang digunakan adalah total sampling. Sampel pada penelitian ini adalah 32 penderita DM tipe II di wilayah Kerja Puskesmas Cawas 1. Alat ukur yang digunakan adalah lembar observasi dan Glucose Cholesteror Acid (GCU). Kesimpulan: ada perbedaan pada rerata kadar gula darah sewaktu pretest-posttest kelompok eksperimen. Tidak ada perbedaan pada rerata kadar gula darah sewaktu pretest-posttest kelompok kontrol. Ada pengaruh senam kaki terhadap kadar gula darah sewaktu pada penderita diabetes melitus tipe II.

Menurut hasil penelitian Penelitian Diah (2019) diabetes Mellitus terjadi akibat penurunan sensitivitas terhadap insulin (resistensi insulin) atau akibat penurunan jumlah produksi insulin Tujuan penelitian ini untuk mengetahui pengaruh senam kaki terhadap kadar gula darah pada lansia diabetes mellitus di Posbindu Anyelir Lubang Buaya.Teknik pengambilan sampel dilakukan dengan simple random sampling dengan jumlah sampel 13 orang Hasil penelitian menggunakan uji paired t-test didapatkan nilai $\mathrm{p}$ - value $=0,000<\alpha=0,05$. Penelitian ini menunjukkan adanya pengaruh senam kaki terhadap kadar gula darah pada lansia diabetes melitus di Posbindu Anyelir Lubang Buaya simpulan diabetes mellitus yang melaksanakan senam kaki 
sesuai indikasi dan memperhatikan kontraindikasi dengan frekuensi 3 kali dalam seminggu selama 30 menit maka terkendali kadar gula darahnya.

Fenomena yang diuraikan diatas dikarenakan penderita diabetes melitus mengalami produksi insulin yang tidak adekuat sehingga mengakibatkan kadar gula dalam darah meningkat. Kondisi tersebut dapat menyebabkan rusaknya saraf, pembuluh darah dan struktur internal lainnya sehingga pasokan darah ke kaki semakin terhambat, efeknya penderita DM merasakan gangguan sirkulasi darah pada kakinya. Senam kaki diberikan kepada penderita diabetes melitus baik tipe 1, tipe 2 dan tipe lainnya dan sangat dianjurkan sebagai langkah pencegahan dini sejak pertama kali penderita dinyatakan menderita dibetes melitus.Senam kaki tergolong olahraga atau ringan yang mudah karena bisa dilakukan di dalam atau diluar ruangan terutama di rumah dengan kursi dan koran serta tidak memerlukan waktu yang lama hanya sekitar 20-30 menit yang berguna untuk menghindari terjadinya luka dan membantu melancarkan peredaran darah bagian kaki Berdasarkan paparan tersebut, peneliti melakukan pelaksanaan terapi senam kaki lalu diukur kadar gula darah pada saat pre dan post senam kaki pada lansia diabetes.

\section{METODE PENELITIAN}

Penelitian ini disusun menggunakan metode deskriptif dengan pendekatan studi kasus yaitu metode ilmiah yang bersifat mengumpulkan data, menganalisis data dan menarik kesimpulan data. Dalam penelitian ini peneliti mengukur sensitivitas kaki pada pasien DM tipe 2 sebelum diberi intervensi senam kaki dan setelah diberikan intervensi senam kaki. Desain rancangan yang dipergunakan yaitu pre and post test group design. Sensitivitas kaki sebelum dan sesudah diberikan intervensi senam kaki dilakukan penilaian untuk melihat pengaruh senam kaki terhadap perubahan sensitivitas kaki penderita diabetes melitus di Ruang rawat inap Rumah Sakit Pelni Jakarta Tahun 2018.

Kriteria inklusi sampel dalam penelitian ini adalah (1) Pasien yang sedang dirawat di Ruang Rawat Inap Dewasa Rumah Sakit Pelni, (2) Pasien yang bersedia untuk menjadi responden dan mengikuti penelitian, (3)Pemeriksaan GDS >180 ml/dl, (4) Pasien dengan umur $>40$ Tahun, (5) Pasien dengan sering merasa kesemutan/kebas dibagian kaki, (6) Pasien dengan penggunaan OHO dan Insulin.Kriteria Eksklusi sample dalam penelitian ini (1) Pasien dengan komplikasi (Ulkus diabetikum, Dispneu), (2) Pasien dengan penyakit penyerta (Gangguan Cardiovaskuler, PPOK, Osteoatritis). (3) Pasien dengan Psikologi tidak stabil (Depresi), (4) TD sistole $>200 \mathrm{mmhg}$.

Instrumen penelitian adalah suatu alat yang digunakan untuk mengukur fenomena alam maupun sekitar yang diamati Instrument yang digunakan dalam penelitian ini adalah lembar inform consent, format observasi (Performance Assessment dan pengukuran Sensitivitas kaki), lembar kuisioner, serta reflek hammer 3 functions sebagai alat untuk mengukur sensitivitas kaki. Hasil pengukuran dibaca dengan nilai point kesensitivitasan.

Kegiatan ini dilakukan selama tujuh kali pertemuan. Catatan kegiatan, kemajuan dan respon dari masing-masing Subjek diringkas dalam bentuk narasi, namun untuk proses lengkapnya disajikan pada lampiran. Sebelumnya mencari klien yang sesuai dengan kriteria inklusi yaitu Pasien yang sedang dirawat di Ruang Rawat Inap Dewasa Rumah Sakit Pelni , Pasien yang bersedia untuk menjadi responden dan mengikuti penelitian., Pasien dengan DM Tipe 2, Pemeriksaan GDS $>180 \mathrm{ml} / \mathrm{dl}$, Pasien dengan umur $>40$ Tahun, Pasien dengan sering merasa kesemutan/kebas dibagian kaki. 
Pasien dengan penggunaan $\mathrm{OHO}$ dan Insulin. Setelah menemukan klien yang memenuhi kriteria tersebut, Pertama kali yang dilakukan saat bertemu klien adalah memperkenalkan diri, mewawancara sedikit mengenai keluhan yang ada diklien sambil melakukan pengkajian fisik serta memperhatikan ciri-ciri klien yang sesuai dengan kriteria inklusi yang sudah ditetapkan.

Setelah itu menjelaskan maksud dan tujuan setelah itu memberitahukan tujuan dari senam kaki tersebut serta meminta persetujuan bersedia/tidak dari Klien untuk mengikuti kegiatan senam kaki ini dan mengkontrak waktu untuk melakukan kegiatan senam kaki ini. Setelah mendapat persetujuan, kemudian melakukan pengukuran nilai sensitivitas kaki, Instrument yang digunakan dalam penelitian ini adalah lembar inform consent, format observasi (Performance Assessment dan pengukuran Sensitivitas kaki), serta reflek hammer 3 functions sebagai alat untuk mengukur sensitivitas kaki. Hasil pengukuran dibaca dengan nilai point ke sensitivitasan. Diukur dengan rentang nilai 0-3 nilai $0=$ tidak ada sensitivitas, nilai $1=$ sensitivitas kurang, nilai $2=$ sensitivitas sedang dan nilai 3 = sensitivitas baik atau normal.

Gunakan format prosedur operasional intervensi senam kaki sesuai dengan performance assessment yang sudah dibuat lakukan penilaian sensitivitas kaki subjek apa yang klien rasakan sebelum intervensi senam kaki dilakukan, kemudian lakukan intervensi senam kaki, dan lakukan kembali pengukuran nilai sensitivitas kaki, lalu membandingkan nilai sensitivitas sebelum dengan setelah dilakukan intervensi senam kaki, hasilnya dianalisa.

\section{HASIL PENELITIAN}

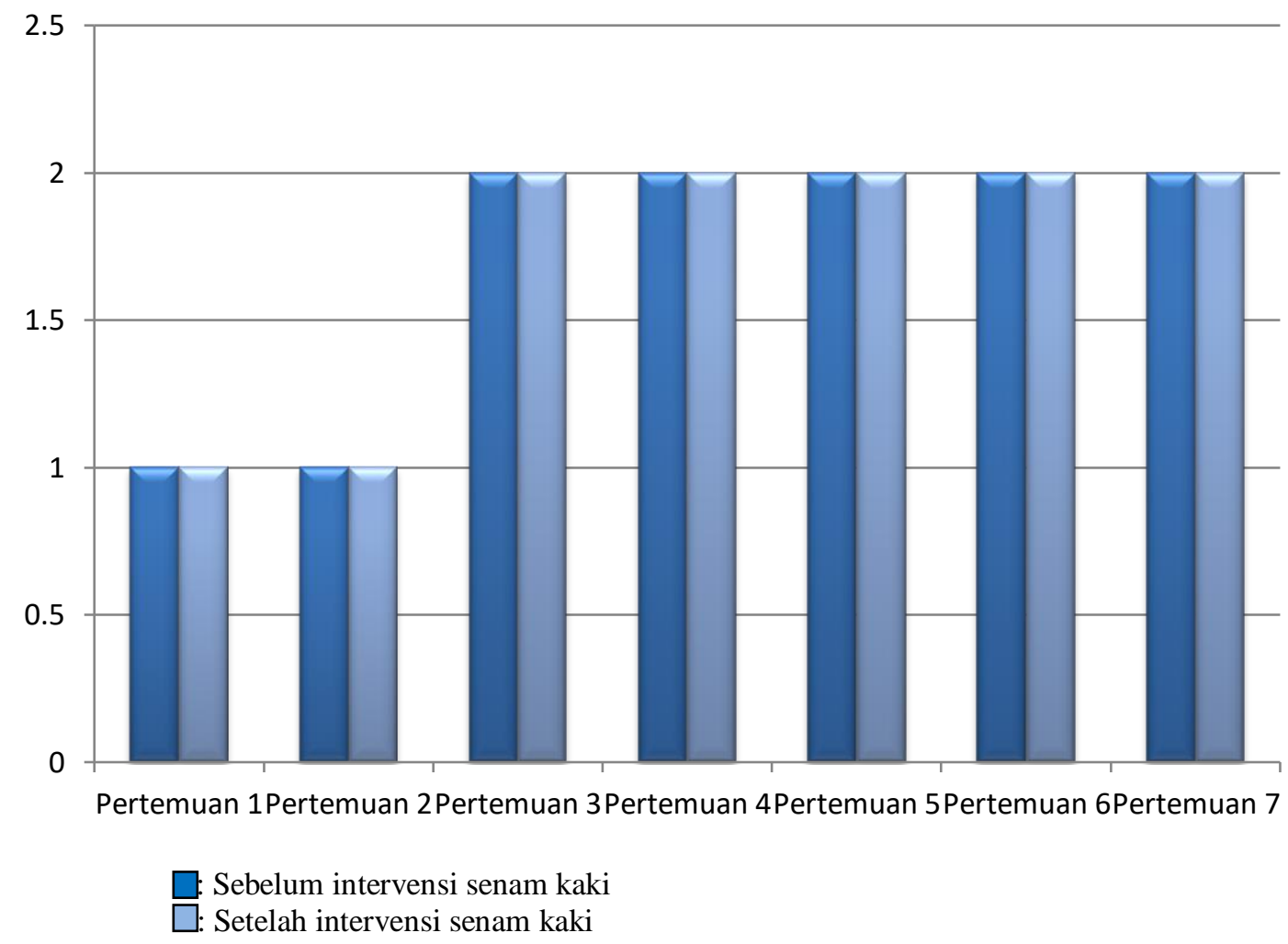

Grafik 1

Nilai Sensitivitas Kaki Kanan 
Pada pertemuan pertama dan kedua sebelum dan setelah dilakukan intervensi senam kaki nilai sensitivitas adalah 1 , pada pertemuan ketiga sampai dengan pertemuan ke tujuh sebelum dan setelah dilakukan intervensi senam kaki dengan nilai sensitifitas adalah 2, hal ini menunjukkan bahwa terjadi peningkatan nilain sensitivitas 1 poin walaupun belum mencapai hasil maksimal yaitu nilai 3

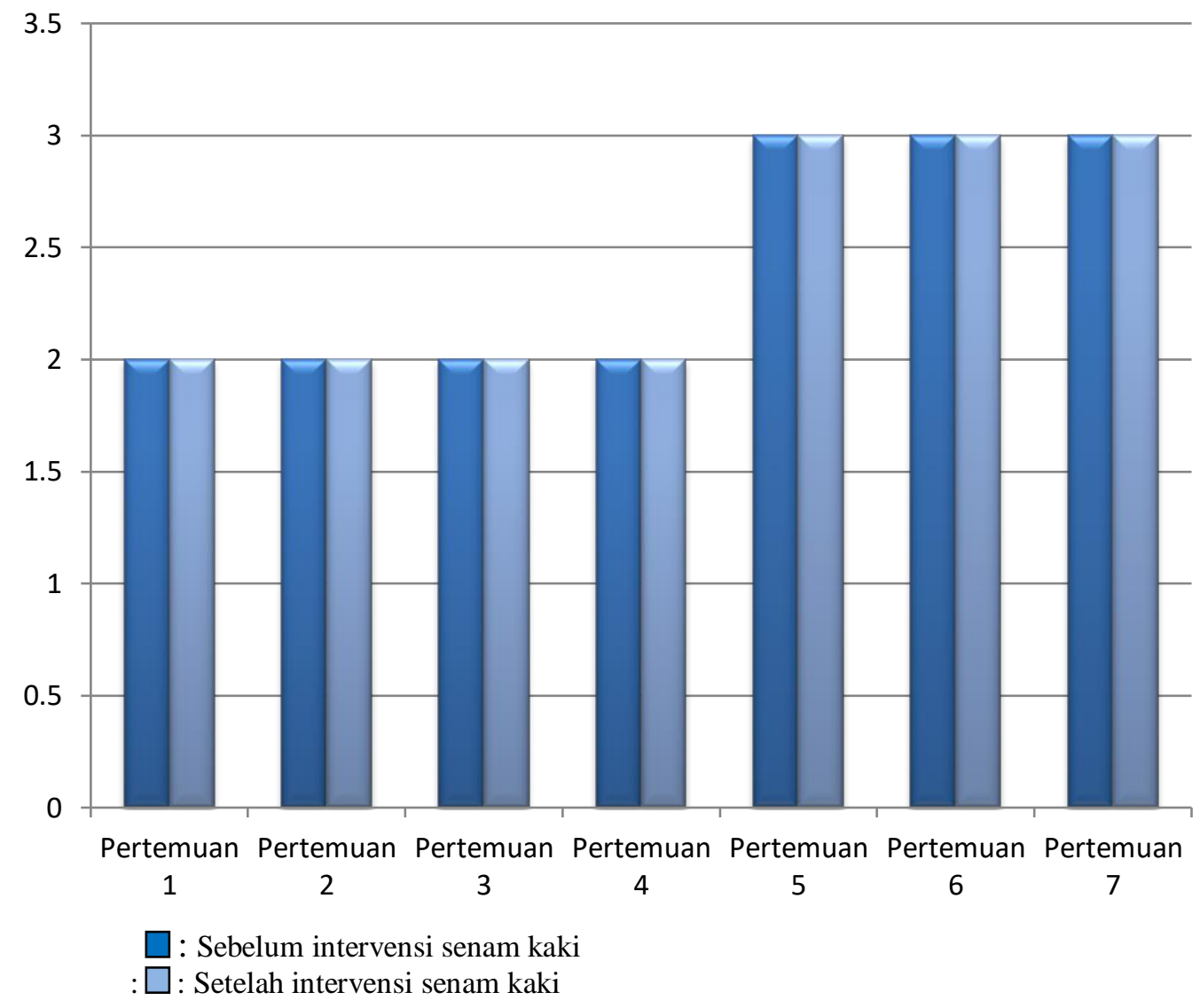

Grafik. 2

Nilai Sensitivitas Kaki Kiri

Pada pertemuan pertama sampai keempat sebelum dan setelah dilakukan intervensi senam kaki nilai sensitivitas adalah 2, pada pertemuan kelima sampai dengan pertemuan ketujuh sebelum dan setelah dilakukan intervensi senam kaki dengan nilai sensitifitas adalah 3, hal ini menunjukkan bahwa terjadi peningkatan nilai sensitivitas 1 poin dan sudah mencapai mencapai hasil maksimal yaitu nilai 3 (normal)

Hasil penelitian pada subjek I sebelum intervensi senam kaki pada pertemuan pertama, nilai sensitivitas kaki Kanan adalah 1 dan nilai Sensitivitas kaki Kiri adalah 2. Nilai sensitivitas kaki Subjek setelah dilakukan intervensi senam kaki sejumlah 7 kali pertemuan hasil pengukuran sensitivitas Kaki kanan dengan nilai 2 dan Kaki kiri hasil pengukuran meningkat mencapai angka maksimal yaitu 3. 


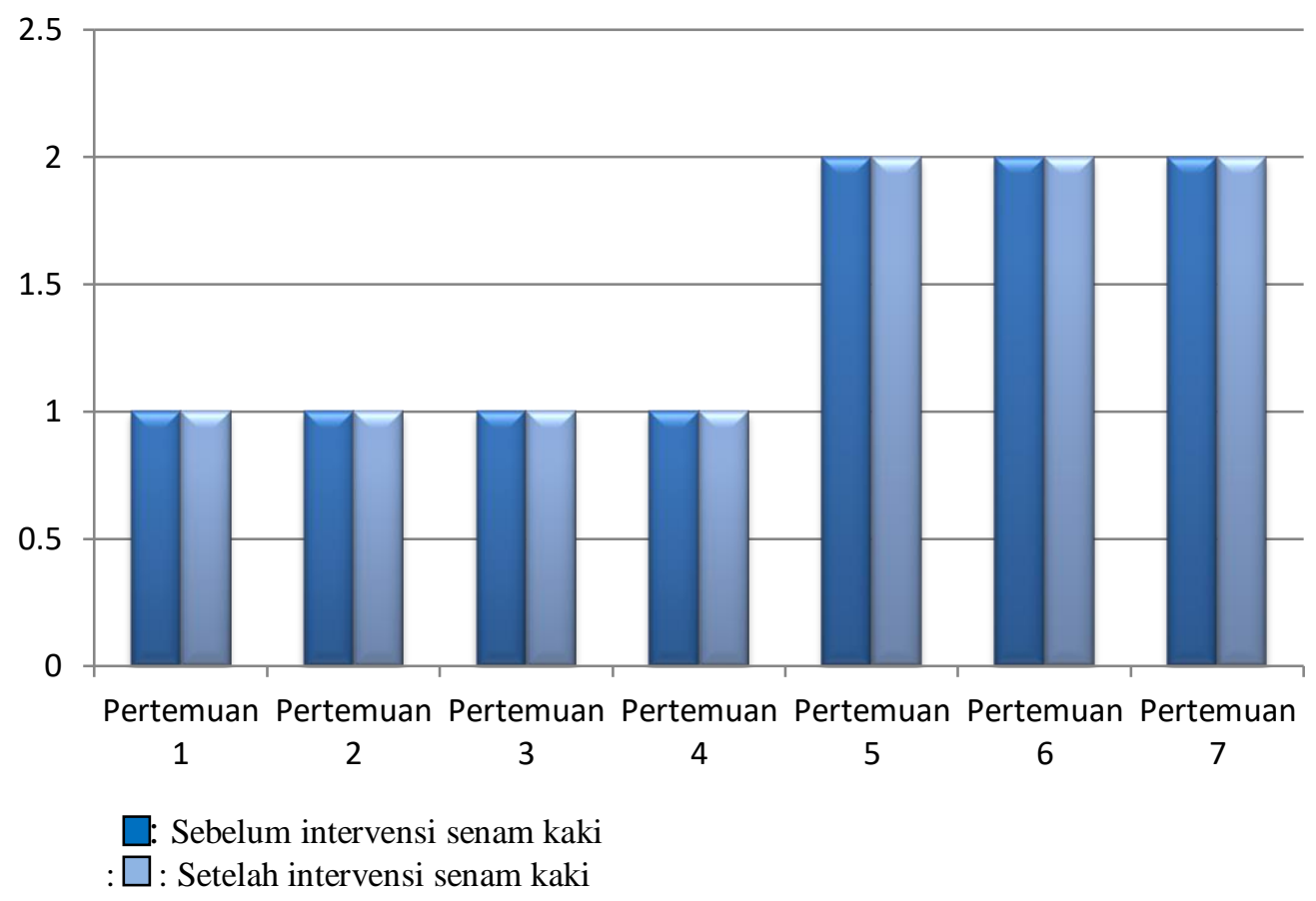

Grafik. 3

Nilai Sensitivitas Kaki Kanan

Pada pertemuan pertama sampai keempat sebelum dan setelah dilakukan intervensi senam kaki nilai sensitivitas adalah 1, pada pertemuan kelima sampai dengan pertemuan ke tujuh sebelum dan setelah dilakukan intervensi senam kaki dengan nilai sensitifitas adalah 2 , hal ini menunjukkan bahwa terjadi peningkatan nilai sensitivitas 1 poin walaupun belum mencapai hasil maksimal yaitu nilai 3 .

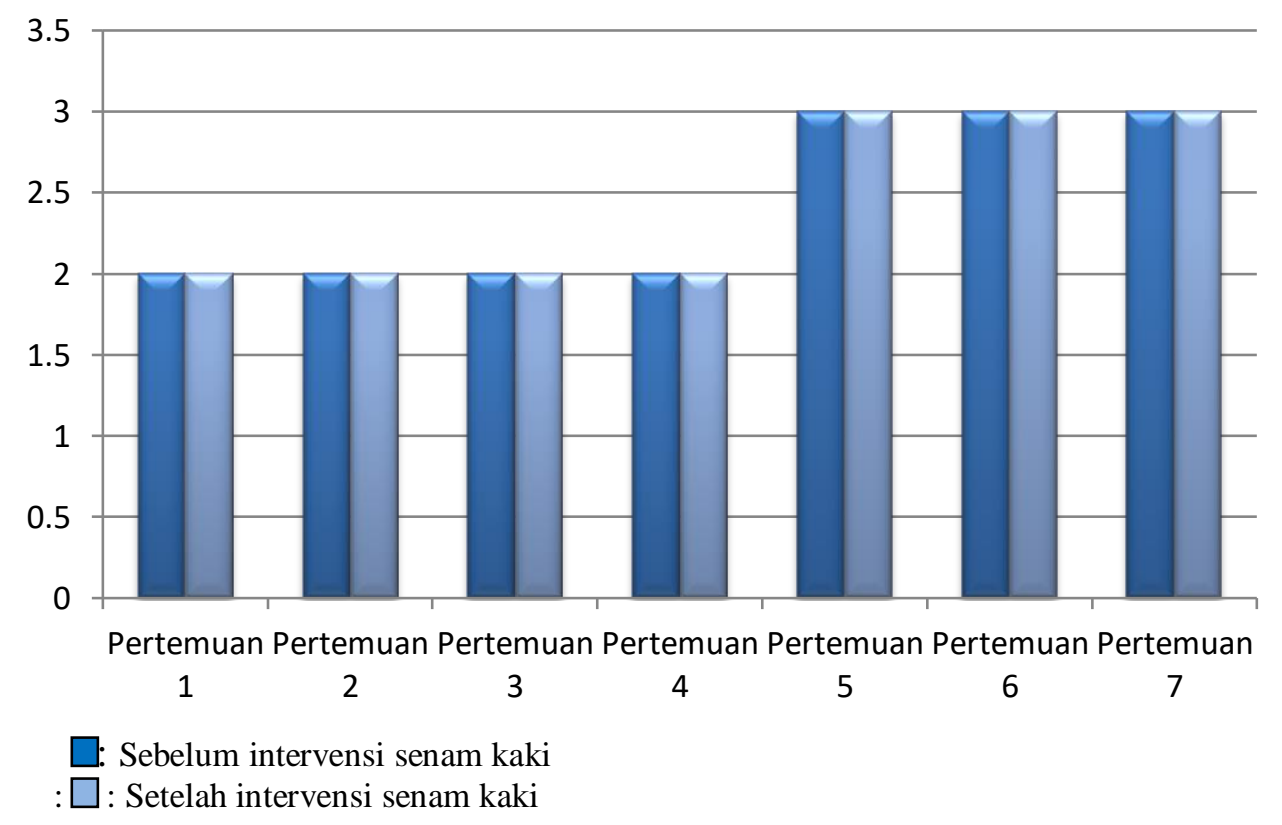

Grafik. 4

Nilai Sensitivitas Kaki Kiri 
Pada pertemuan pertama sampai keempat sebelum dan setelah dilakukan intervensi senam kaki nilai sensitivitas adalah 2, pada pertemuan kelima sampai dengan pertemuan ke tujuh sebelum dan setelah dilakukan intervensi senam kaki dengan nilai sensitifitas adalah 3, hal ini menunjukkan bahwa terjadi peningkatan nilai sensitivitas 1 poin dan telah mencapai hasil maksimal yaitu nilai 3

Hasil penelitian pada subjek II sebelum intervensi senam kaki pada pertemuan pertama, nilai sensitivitas kaki Kanan adalah 1 dan nilai Sensitivitas kaki kiri adalah 2. Nilai sensitivitas kaki subjek setelah dilakukan intervensi senam kaki sejumlah 7 kali pertemuan hasil pengukuran sensitivitas Kaki kanan dengan nilai 2 dan Kaki kiri hasil pengukuran meningkat mencapai angka maksimal yaitu 3. Sedangkan hasil penelitian

\section{PEMBAHASAN}

Hasil penelitian pada subjek I dan subjek II sebelum intervensi senam kaki pada pertemuan pertama, nilai sensitivitas kaki Kanan adalah 1 dan nilai Sensitivitas kaki Kiri adalah 2. Nilai sensitivitas kaki Subjek setelah dilakukan intervensi senam kaki sejumlah 7 kali pertemuan hasil pengukuran sensitivitas Kaki kanan meningkat 1 poin menjadi nilai 2 dan Kaki kiri hasil pengukuran meningkat 1 poin mencapai angka maksimal yaitu 3 .

Peningkatan nilai sensitivitas kaki ini disebabkan karena selama proses inter vensi kedua Subjek menunjukkan perilaku yang kooperatif sehingga saat dilakukan intervensi didapatkan hasil perubahan sensitivitas kaki yang cukup signifikan. Kondisi itu kemungkinan dikarenakan gerakan-gerakan yang ada pada senam kaki dapat memperlancar peredaran darah di ektremitas bawah, menguatkan otot kaki, mencegah kelainan bentuk pada kaki dan mengatasi keterbatasan gerak sendi.

Hasil Penelitian Khaerunnisa (2019) senam kaki merupakan salah satu tindakan keperawatan yang dapat menurunkan gluko sa darah dan sensitivitas kaki. Instrumen yang digunakan adalah pedoman wawancara, lembar ceklist dan catatan dokumentasi pasien. Data dianalisis berdasarkan hasil wawancara, pengukuran glukosa darah sewaktu dan sensitivitas kaki sebelum dan sesudah latihan senam kaki. Hasil penelitian menunjukkan penurunan gula darah sewaktu sebanyak $75 \%$ responden sesudah latihan senam kaki pada latihan ketiga dengan frekuensi latihan 3 kali seminggu. Sebanyak $25 \%$ responden tidak mengalami perbaikan akibat tidak mampu mengontrol diet. Hal ini berpengaruh pada peningkatan sensitivitas kaki pada responden. Faktor yang mendukung penurunan glukosa darah sewaktu dan peningkatan sensitivitas kaki pasien adalah pengontrolan diet, aktivitas atau olah raga, stress dan istirahat. Simpulan penelitian menunjukan bahwa penderita DMT2 yang melakukan senam kaki 3kali seminggu mengalami penurunan glukosa darah sewaktu yang akan mempengaruhi peningkatan sensitivitas kaki.

Muhammad Ngadiluwih (2018) penelitian tersebut menunjukkan bahwa sensitivitas kaki pasien Diabetes yang mengalami masalah berkaitan dengan mati rasa dan penurunan sensitivitas pada kaki dengan dilakukan intervensi senam kaki, sensitivitas dapat meningkat. Oleh karena itu pasien Diabetes Melitus yang mengalami penurunan kemampuan untuk merasakan rangsangan pada kaki, mudah merasa nyeri atau nyeri tekan sangat diperlukan latihan fisik secara rutin agar sirkulasi darah pada daerah kaki dan saraf tepi tidak tersumbat atau mengalami hambatan. Hasil penelitian ini menunjukkan ada pengaruh senam kaki Diabetes terhadap tingkat sensitivitas kaki pada pasien diabetes melitus. 
Penelitian Putra (2020) menggunakan pendekatan pre eksperimental design dengan rancangan one group pretest posttest design. Sampel terdiri dari 54 responden. Teknik sampling yang digunakan adalah non probability sampling yaitu purposive sampling, pengumpulan data me nggunakan lembar observasi pengukuran nilai ABI. Hasil uji statistic Paired $\mathrm{T}$-Test didapatkan nilai $\mathrm{p}=0,001$ yang berarti ada pengaruh senam kaki terhadap nilai ankle brachial index pada penderita DM Tipe 2 di Wilayah Kerja Puskesmas Banjar II. Dari hasil penelitian, ditemukan bahwa semakin bertambahnya usia semakin beresiko mengalami gangguan pada peredaran darah. Dimana responden dengan usia lanjut berada pada kategori penyakit vaskuler sedang.

Sejalan dengan peneitian Margaretta (2017) menunjukkan hasil rata-rata sensitivitas kaki individu pada kelompok senam kaki dan kelompok kontrol terdapat peningkatan, rata-rata resiko jatuh pada kelompok senam kaki dan kelompok kontrol mengalami penurunan, Dapat disimpulkan bahwa intervensi senam kaki efektif 23,05\% meningkatkan sensitivitas kaki lansia.

Penelitian Puspita (2019) senam kaki diabetik merupakan kegiatan atau latihan yang dilakukan oleh pasien diabetes melitus untuk mencegah terjadinya luka dan membantu melancarkan peredaran darah bagian kaki. Tujuan umum penelitian ini adalah untuk mengetahui pengaruh senam kaki diabetik dengan menggunakan Koran terhadap penurunan kadar gula darah pada penderita DM tipe 2 di Rt.01/04 Desa Parigi Lama Pondok Aren Tangerang Selatan Penelitian ini menggunakan penelitian quasi eksperimenal design (eksperimen semu) dengan pendekatan one group pretest dan posttest, yaitu eksperimen yang dilaksanakan pada satu kelompok saja tanpa kelompok pembanding (control). Populasi dalam penelitian ini adalah penderita diabetes melitus tipe 2 berjumlah 16 orang, sampel berjumlah 16 responden menggunakan tehnik nonprobability sampling dengan teknik incidental sampling. Alat pengumpulan data adalah lembar observasi. Sedangkan analisis data uji Wilcoxon. Berdasarkan analisis data dengan uji analisis wilcoxon dengan derajat kemaknaan $\leq 0,05 \quad(5 \%)$, didapatkan rata-rata kadar gula darah sebelum senam kaki diabetik 236,69 mg/dl dan sesudah senam kaki diabetik adalah 186,25 mg/dl. Hasil uji statistik menunjukkan bahwa $p$ value sebesar 0,000 yang lebih kecil dari nilai $\alpha(0,05)$. Hal ini menunjukan bahwa ada pengaruh senam kaki diabetik dengan menggunakan koran terhadap penurunan kadar gula darah pada penderita DM Tipe 2 di Rt.01/04 Desa Parigi Lama Pondok Aren Tangerang Selatan.

\section{SIMPULAN}

Pelaksanaan senam kaki dapat memberikan hasil yang efektif dengan meningkatnya sensitivitas kaki pada pasien Diabetes Melitus yang mengalami penurunan sensitivitas pada kaki, setelah dilakukan senam kaki secara teratur cenderung sensitivitas kaki meningkat dibandingkan sebelum dilakukan intervensi senam kaki. senam kaki mempengaruhi penurunan kadar gula darah sewaktu. Adanya peningkatan GDS setelah latihan disebabkan oleh faktor ketidakpatuhan diet, stress, kurang tidur dan aktivitas/olah raga. Selain itu,senam kaki mempengaruhi peningkatan sensitivitas kaki, dimana ditemukan perbaikan sensitivitas kaki pada pasien. 


\section{SARAN}

\section{Bagi Masyarakat}

Diharapkan dapat mengerti dan melaksanakan senam kaki sehingga dapat meningkatkan sensitivitas kaki .

\section{Bagi Intitusi Pendidikan.}

Hasil penelitian ini dapat dijadikan bahan informasi pendidikan sehingga saat mahasiswa melakukan asuhak keperawatan pada penderita diabetes melitus mahasiswa dapat mengetahui salah satu penatalaksanaan non farmakologi yang bisa dilakukan dalam memberikan asuhan.

\section{Bagi Pelayanan Kesehatan,}

Pelayanan kesehatan masyarakat seperti Rumah sakit dan instansi kesehatan lainnya hendaknya mengaplikasikan penatalaksanaann intervensi non farmakologi senam kaki dalam pelaksanaannya. Perawat juga dapat memberikan informasi tentang pengaruh senam kaki terhadap sensitivitas kaki.

\section{Bagi Ilmu Keperawatan dan Penelitian Selanjutnya,}

Penelitian ini dapat dijadikan referensi bagi peneliti selanjutnya untuk dapat melakukan penelitian yang terkait dengan pengaruh intervensi senam kaki terhadap sensitivitas kaki.

\section{DAFTAR PUSTAKA}

Anggraini, S. S. (2017). Pengaruh Senam Kaki terhadap Kadar Gula Darah Sewaktu pada Penderita Diabetes Melitus Tipe II di Wilayah Kerja Puskesmas Cawas I. http://digilib.unisayogya.ac.id/2509/1/naskah\%20publikasi.pdf

Diah, R. (2019). Pelaksanaan Senam Kaki Mengendalikan Kadar Gula Darah pada Lansia Diabetes Melitus di Posbindu Anyelir Lubang Buaya. Jurnal Ilmiah Kesehatan Masyarakat. 11

Fatimah, R. N. (2015). Diabetes Melitus Tipe 2. Journal Majority, 4, 93-101

IDF. 2015. Idf Diabetes Atlas Sixth Edittion. Diakses pada tanggal 28 November 2016 dari https://www.idf.org/sites/default/files/Atlas-poster-2015_EN.pdf

Khaerunnisa, N. (2019). Penerapan Senam Kaki pada Pasien Diabetes Mellitus Tipe 2 dalam Pemenuhan Kebutuhan Keamanan dan Proteksi (Integritas Kulit/Jaringan) di Wilayah Kerja Puskesmas Mamajang Jurnal Media Keperawatan: Politeknik Kesehatan Makassar. 9(2)

Margaretha, S. S. (2017). Efektivitas Senam Kaki Diabetes terhadap Sensitifitas Kaki dan Resiko Jatuh pada Lansia. http://sheyla.com.senamkakidiabetes/2018

Ngadiluwih, M. S. (2018). Pengaruh Perawatan Kaki terhadap Sesitivitas Kaki pada Penderita Pasien Diabetes Mellitus Tipe 2. Skripsi. http://repo.stikesicmejbg.ac.id/1509/

Padila, P (2012). Buku Ajar Keperawatan Medikal Bedah. Yogyakarta: Nuha Medika

Perkeni. (2015). Konsensus Pengelolalan dan Pencegahan Diabetes Mellitus Tipe Indonesia. Retrieved Desember 28, 2016, from www.perkeni.org

Puspita, R. R. (2019). Pengaruh Senam Kaki Diabetik Menggunakan Koran terhadap Penurunan Kadar Gula Darah Penderita Dm Tipe 2 di Pondok Aren Tangerang Selata http://openjournal.masda.ac.id/index.php/edumasda/article/view/28

Putra, M. M. (2020). Efektifitas Senam Kaki terhadap Nilai Ankle Brachial Index pada Penderita Diabetes Mellitus Tipe 2. Jurnal Ilmiah Keperawatan (Scientific Journal Of Nursing). 6(1) 
Sulistyowati, A. S., \& Asnindari, L. N. (2017). The Effect of Foot Exercise on the Blood Glucose Level Of Diabetes Melitus Patients Type II In Cawas Public Health Cente

WHO (World Health Organization). (2015). Prevalence of Raised Diabetes Mellitus. Retrieved from https://www.who.int/healt-topics/diabetesmelitus/ 